\title{
Pyogenic liver abscess in a diabetic patient with fever of unknown origin
}

\author{
Adina Ilie, Ramona Popescu, Elisabeta Stoica \\ From The 9th Edition of the Scientific Days of the National Institute for Infectious Diseases Prof Dr Matei \\ Bals \\ Bucharest, Romania. 23-25 October 2013
}

\section{Background}

We present the management of febrile syndrome in a diabetic patient.

\section{Case report}

The patient was admitted to our ward from a county hospital to establish the diagnosis of a 25-day fever and cough. The following diagnoses had been excluded: HIV, endocarditis, pneumonia, urinary tract infection and the infection appeared not to respond to ampicillin- sulbactam or levofloxacin. However, an abdominal ultrasound had not been performed.

From the medical history we noted that the patient had poorly managed diabetes mellitus type 2 and hypertension with mild cardiac disease.

We performed an abdominal ultrasound and identified a large liver abscess, confirmed by contrast enhanced CT scanning.

The patient was treated with antibiotics and after 14 days the abscess was drained under $\mathrm{CT}$ guidance. The etiology was established to be $E$ coli.

At the present the patient is doing very well - he is still under antibiotic treatment with drain tube and ultrasound monitoring.

\section{Conclusion}

The diagnosis in a patient with fever of unknown origin and cough turned out to be pyogenic liver abscess with good evolution under antibiotic treatment and CT guided drainage.

Published: 16 December 2013

* Correspondence: adinailie00@yahoo.com

National Institute for Infectious Diseases "Prof. Dr. Matei Balş", Bucharest, Romania

C Biomed Central

○ 2013 llie et al; licensee BioMed Central Ltd. This is an Open Access article distributed under the terms of the Creative Commons Attribution License (http://creativecommons.org/licenses/by/2.0), which permits unrestricted use, distribution, and reproduction in any medium, provided the original work is properly cited.
doi:10.1186/1471-2334-13-S1-P97

Cite this article as: Ilie et al:: Pyogenic liver abscess in a diabetic patient with fever of unknown origin. BMC Infectious Diseases 2013 13(Suppl 1):P97.
Submit your next manuscript to BioMed Central and take full advantage of:

- Convenient online submission

- Thorough peer review

- No space constraints or color figure charges

- Immediate publication on acceptance

- Inclusion in PubMed, CAS, Scopus and Google Scholar

- Research which is freely available for redistribution Submit your manuscript at
www.biomedcentral.com/submit C Biomed Central 